\title{
Air Pollution in the Gulf of Mexico
}

\author{
Manuel Muriel-García1, Rosa María Cerón-Bretón², Julia G. Cerón-Bretón² \\ ${ }^{1}$ Instituto Mexicano del Petróleo, Ciudad del Carmen, México \\ ${ }^{2}$ Facultad de Química, Universidad Autónoma del Carmen, Ciudad del Carmen, México \\ Email: jceronbreton@pampano.unacar.mx
}

Received 10 November 2015; accepted 15 January 2016; published 18 January 2016

Copyright (C) 2016 by authors and Scientific Research Publishing Inc.

This work is licensed under the Creative Commons Attribution International License (CC BY).

http://creativecommons.org/licenses/by/4.0/

\begin{abstract}
An integral analysis of Air Pollution in the Gulf of Mexico was made considering pollutants emissions assessment and diagnosis; air pollution monitoring; and modeling of air pollution dispersion. Combustion sources considered in this work were: thermoelectric power plants and open flares; and pollutants considered were sulfur dioxide, nitrogen dioxides, particulate matter $\left(\mathrm{PM}_{10}\right.$ and $\mathbf{P M}_{2.5}$ ), Total suspended particles (TSP) and carbon monoxide (CO). This study made evident a lack of more recent information and a homogenization in emissions factors in order to know the conditions of air pollution in the Gulf of Mexico in a more reliable way.
\end{abstract}

\section{Keywords}

Air Pollution, Dispersion Models, Air Pollution Monitoring, Gulf of Mexico

\section{Introduction}

In past years, a few efforts were made to diagnosis/assess air pollution from main sources in the Gulf of Mexico. Recently, some researchers have provided more information to help to understand an old pollution problem [1]-[11]. Nevertheless, there is not a systematic set of information that can allow an integral analysis of Air Pollution in the Gulf of Mexico.

In this paper, we present the results of our review and attempt to make an integral analysis covering three main topics:

- Pollutants Emissions Assessment and Diagnosis.

- Air Pollution Monitoring.

- Modeling of Air Pollution Dispersion.

It is important to mention that pollution information is scarce and that some of it is not public. Pollutants referred in this work are those mainly emitted by combustion sources such as thermoelectric power plants and open flares: sulfur dioxide $\left(\mathrm{SO}_{2}\right)$, nitrogen oxides $\left(\mathrm{NO}_{\mathrm{x}}\right)$, particulate matter fraction $10 \mu \mathrm{m}\left(\mathrm{PM}_{10}\right)$, particulate 
matter fraction $2.5 \mu \mathrm{m}\left(\mathrm{PM}_{2.5}\right)$, Total Suspended particles (TSP) and carbon monoxide (CO). There is also some information about Non-Methane Hydrocarbons (NMHC), Volatile Organic Compounds (VOC) and Total Organic Compounds (TOC) that might be emitted in some petroleum storage and transport processes and in some extent in combustion process.

\section{Study Area}

Currently, the states bordering the Gulf of Mexico have more than $17 \times 10^{6}$ inhabitants, contributing with almost $15 \%$ of the total population in Mexico. More than $30 \%$ of this population is concentrated within 9 major cities with more than 220,000 inhabitants, these urban centers are Mérida, Yucatán; Cancun, Quintana Roo; Reynosa, Tamaulipas; Matamoros, Tamaulipas; Veracruz, Veracruz; Villahermosa, Tabasco; Tampico, Tamaulipas; Coatzacoalcos, Veracruz; and Campeche, Campeche. Oil industry, tourism, maritime transport, livestock farming, and agriculture are the main economical activities in the coastal zone of the Gulf of Mexico, contributing with approximately $16 \%$ of the gross domestic product (GDP). The region of the Gulf of Mexico produces daily $2.5 \times 10^{6}$ petroleum barrels ( $98 \%$ of the total production in the country) and it has $75 \%$ of the total installed capacity to obtain and process this mineral resource. The main activities in Tamaulipas State are port activities (importation and exportation) and fish production. In the case of Veracruz, this state ranks first in petrochemical production, electricity production and livestock farming, other important activities in Veracruz are sugar cane production and maritime transport. On the other hand, Tabasco and Campeche States have increased their contribution to GDP due to oil and gas industry, other activities in this region are fishery and cattle raising. Finally, in the case of Quintana Roo, its economy is mainly based on tourism industry.

Information found for this work covers these major cities which are located along the coast of Gulf of Mexico, this region is displayed in Figure 1.

During the period 1995-2000, the National Institute of Ecology (INE) with the technical and economical support from the Environment Protection Agency of the United States (US EPA) developed and applied for first time in Mexico an appropriate methodology for the particular conditions of Mexico to estimate emissions inventory at a national scale. In addition, the main metropolitan zones in the country (Valley of Mexico, Guadalajara, Monterrey and Toluca), the main border towns (Mexicali, Tijuana and Ciudad Juarez), and some cities such as Salamanca, Guanajuato and Puebla, have developed disaggregated inventories as part of the programs to improve the air quality in these regions, unfortunately, these emissions inventories have differences in the inventories characteristics, activity data and estimation methods with respect to those used in the National Emissions
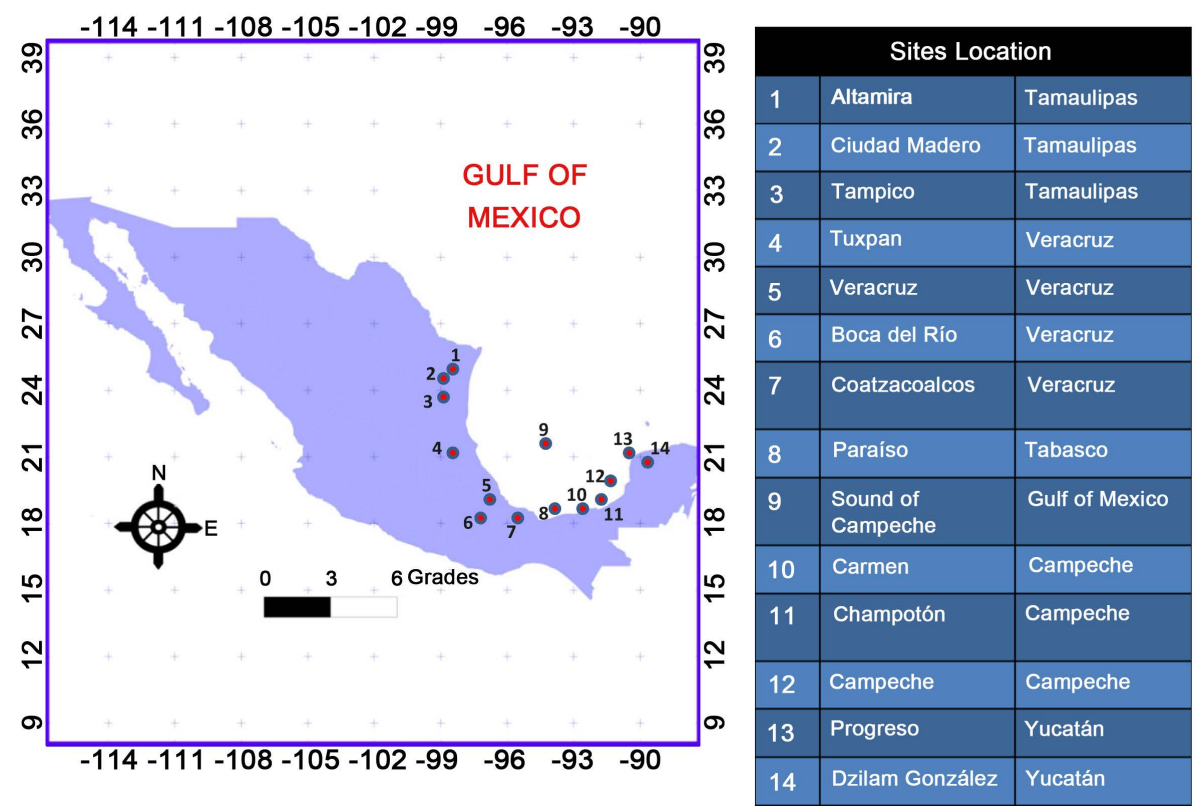

Figure 1. Main cities of Mexico which are located in the Gulf of Mexico. 
Inventory of Mexico (INEM) [1]. Therefore, it has not been possible to integrate these results to the National Inventory, making impossible any comparison between them.

The results of the National Emissions Inventory of Mexico for the states located along the coast of the Gulf of Mexico are presented in Table 1 [2]. From this, it can be observed that activities linked to the petroleum industry, the coastal zone of Tabasco, and the south region of Campeche and Veracruz states, show the highest concentration of air pollution sources, contributing with 227, 197 and $32 \mathrm{Gg} \cdot \mathrm{yr}^{-1}$, respectively [3]. The main pollutants emitted from these sources are sulfur oxides $\left(\mathrm{SO}_{\mathrm{x}}\right)$, nitrogen oxides $\left(\mathrm{NO}_{\mathrm{x}}\right)$ and volatile organic compounds (VOC's), which constitute approximately $60 \%, 12 \%$ and $8 \%$ of the total emissions, respectively. The main fixed sources of these pollutants are: the industrial sector in the border of Tamaulipas with Texas [4]; port and industrial zone in Altamira [5]; oil fired power plants in Tuxpan [6] [7]; chemical and petrochemical industry in Coatzacoalcos [5]; Dos Bocas Maritime Terminal (DBMT) in Paraíso, Tabasco [8]; offshore oil and gas production area in the Sound of Campeche [9] [10], and gas recompression station in Atasta, Campeche [8] [11].

\section{Pollutants Emissions Assessment and Diagnosis}

In 1999, Muriel [12] [13] carried out the first air pollution emission inventory (EI) in the Sound of Campeche [12] [13]. This endeavor covered only some offshore platforms: Abkatun-A, Abkatun-D, Abkatun-N, Pool-A and Dos Bocas Maritime Terminal (DBMT), located in the southwest operations of oil industry in the Sound of Campeche. From the main results it can be concluded that none of the emitted pollutants was above maximum allowed level in the Mexican Regulatory. In the EI for this work were reported $1.29 \mathrm{KTon}^{\cdot} \mathrm{yr}^{-1}$ of $\mathrm{NO}_{\mathrm{x}}$ and 18.96 $\mathrm{KTon} \cdot \mathrm{yr}^{-1}$ of $\mathrm{SO}_{2}$. These estimations only considered southwest operations of oil industry, which was less than half of total production in 1999 in the Sound of Campeche, they are more in agreement with $16.01 \mathrm{KTon}^{-\mathrm{yr}^{-1}}$ and $51.83 \mathrm{KTon} \cdot \mathrm{yr}^{-1}$, which are for all the region [14] [15].

An EIof all offshore operations for the exploration and production of petroleum by the Mexican Oil Industry, in the Sound of Campeche, was performed by Villaseñorr et al. [8], where primary pollutants emissions were obtained by means of emission factors reported in the literature. They described results for the 1999 period, including $\mathrm{NO}_{\mathrm{x}}, \mathrm{SO}_{2}, \mathrm{H}_{2} \mathrm{~S}, \mathrm{CO}$, NMHC and $\mathrm{PM}_{10}$. They claim to be the first emission inventory for the Sound of Campeche region, but it showed some differences with other EI for the same region [9] [14]-[16], $\mathrm{SO}_{2}$ is in good agreement, but $\mathrm{NO}_{\mathrm{x}}$ seems to be overestimatedand $\mathrm{H}_{2} \mathrm{~S}, 1.1 \mathrm{KTon} \cdot \mathrm{yr}^{-1}$, is much lower than $9.10 \mathrm{KTon} \cdot \mathrm{yr}^{-1}$ value reported a few years later [8], even though this reported value is an average for part of 2001 year.They argue that previous work did not consider combustion efficiency due to local meteorological conditions [8], although they also employed literature emission factors as well. Gas consumption for November 2000 to November 2001 period was used for this study as well as meteorological information from the same area (see Table 2).

The most recent information available was published by SEMARNAT [17]. This report covers all Mexican Republic, but it has not sufficient detail to make a straight comparison with some other EI [8]-[18]. Still some important information can be retrieved. For instance, total pollutants emissions in Gulf of Mexico produced by Mexico's coastal places amounts $1,973,096.32 \mathrm{KTon} \cdot \mathrm{yr}^{-1}$. Total major contributions are for $\mathrm{SO}_{2}(725,616.8$

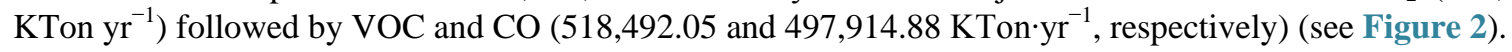

Table 1. Emissions inventory of atmospheric pollutants in the states located along the coast of the Gulf of Mexico [1].

\begin{tabular}{|c|c|c|c|c|c|c|}
\hline \multirow{2}{*}{ State } & \multicolumn{6}{|c|}{ Emissions (Gg· $\left.\mathrm{yr}^{-1}\right)$} \\
\hline & $\mathrm{CO}$ & $\mathrm{NO}_{\mathrm{x}}$ & $\mathrm{SO}_{2}$ & $\mathrm{PM}_{2.5}$ & $\mathrm{PM}_{10}$ & VOC's \\
\hline Tamaulipas & 11.74 & 15.22 & 151.9 & 4.26 & 6.29 & 26.8 \\
\hline Veracruz & 20.1 & 46.8 & 336.71 & 49.93 & 78.15 & 40.59 \\
\hline Tabasco & 22.98 & 8.99 & 145.45 & 10.06 & 18.21 & 21.88 \\
\hline Campeche & 13.86 & 23.04 & 150.89 & 2.54 & 3.76 & 3.1 \\
\hline Yucatán & 0.32 & 3.32 & 27.94 & 1.51 & 1.87 & 1.7 \\
\hline Quintana Roo & 0.72 & 1.66 & 1.02 & 0.47 & 0.94 & 0.63 \\
\hline
\end{tabular}


Table 2. Air pollutants emissions in the Gulf of Mexico (kton· $\mathrm{yr}^{-1}$ ).

\begin{tabular}{|c|c|c|c|c|c|c|c|c|c|c|c|c|c|c|}
\hline Place & CO & $\mathrm{CO}_{2}$ & $\mathrm{H}_{2} \mathrm{~S}$ & $\mathbf{N H}_{3}$ & $\begin{array}{c}\text { NMH } \\
\text { C }\end{array}$ & $\mathbf{N O}_{\mathbf{x}}$ & $\mathbf{P M}_{2.5}$ & $\mathbf{P M}_{10}$ & $\mathrm{SO}_{2}$ & Soot & TOC & TSP & VOC & Reference \\
\hline $\begin{array}{c}\text { Altamira } \\
\text { Tamaulipas }\end{array}$ & - & 6367.9 & - & - & - & 11.85 & - & - & 116.12 & - & - & - & - & [18] \\
\hline $\begin{array}{c}\text { Altamira } \\
\text { Tamaulipas }\end{array}$ & - & 6201.2 & - & - & - & 12.03 & - & - & 110.89 & - & - & - & - & [18] \\
\hline $\begin{array}{c}\text { Altamira } \\
\text { Tamaulipas }\end{array}$ & $16,276.37$ & - & - & 1413.8 & - & $13,280.5$ & 3756.0 & 4646.4 & $18,933.3$ & 336.8 & - & - & $28,831.7$ & [17] \\
\hline $\begin{array}{c}\text { Boca del Río } \\
\text { Veracruz }\end{array}$ & $45,039.55$ & - & - & 344.99 & - & 7062.93 & 85.46 & 98.61 & 59.11 & 14.39 & - & - & 6286.25 & [17] \\
\hline $\begin{array}{l}\text { Campeche } \\
\text { Campeche }\end{array}$ & - & 938.23 & - & - & - & 1.18 & - & - & 20.91 & - & - & - & - & [18] \\
\hline $\begin{array}{l}\text { Campeche } \\
\text { Campeche }\end{array}$ & - & 796.03 & - & - & - & 1.01 & - & - & 17.74 & - & - & - & - & [18] \\
\hline $\begin{array}{l}\text { Campeche } \\
\text { Campeche }\end{array}$ & $28,291.0$ & - & - & 1330.3 & - & $15,983.3$ & 1655.1 & 2079.1 & $19,266.7$ & 171.7 & - & - & $53,090.9$ & [17] \\
\hline $\begin{array}{l}\text { Campeche } \\
\text { Campeche }\end{array}$ & $31,354.8$ & - & - & 1303.2 & - & $50,024.3$ & 3502.8 & 3764.1 & 556.129 & 280.2 & - & - & $133,602.2$ & [17] \\
\hline $\begin{array}{l}\text { Champotón } \\
\text { Campeche }\end{array}$ & $14,370.34$ & - & - & 1191.9 & - & $13,022.3$ & 2083.9 & 2743.5 & 611.01 & 331.5 & - & - & $201,971.1$ & [17] \\
\hline $\begin{array}{l}\text { Cd Madero } \\
\text { Tamaulipas }\end{array}$ & $67,535.96$ & - & - & 1695.8 & - & 5856.60 & 1637.4 & 2676.0 & $28,420.7$ & 39.09 & - & - & $15,401.4$ & [17] \\
\hline $\begin{array}{l}\text { Coatzacoalcos } \\
\text { Veracruz }\end{array}$ & $70,481.07$ & - & - & 743.35 & - & $13,002.44$ & 559.51 & 603.31 & 1293.91 & 70.84 & - & - & $15,888.91$ & [17] \\
\hline $\begin{array}{l}\text { Dzilam } \\
\text { Gonzalez } \\
\text { Yucatán }\end{array}$ & 588.61 & - & - & 112.07 & - & 1768.38 & 69.34 & 77.85 & 1.29 & 9.48 & - & - & 5624.57 & [17] \\
\hline $\begin{array}{l}\text { Paraíso } \\
\text { Tabasco }\end{array}$ & 6608.49 & - & - & 206.50 & - & 6834.97 & 566.33 & 607.68 & 362.74 & 104.2 & - & - & 6328.62 & [17] \\
\hline $\begin{array}{l}\text { Progreso } \\
\text { Yucatán }\end{array}$ & 3211.07 & - & - & 190.31 & - & 760.19 & 233.85 & 258.19 & 797.89 & 45.55 & - & - & 5494.15 & [17] \\
\hline $\begin{array}{l}\text { Sound of } \\
\text { Campeche }\end{array}$ & 145.51 & - & 1.10 & - & 276.84 & 41.16 & - & 14.43 & 181.00 & - & - & - & - & [8] \\
\hline $\begin{array}{c}\text { Sound of } \\
\text { Campeche }\end{array}$ & 146.42 & - & 14.3 & - & 277.59 & 182.69 & - & - & 185.91 & - & - & 14.7 & - & [9] \\
\hline $\begin{array}{l}\text { Sound of } \\
\text { Campeche }\end{array}$ & 5.09 & 340.61 & 9.10 & - & - & 0.94 & - & - & 4.07 & - & 447.6 & 0.06 & - & [10] \\
\hline $\begin{array}{l}\text { Sound of } \\
\text { Campeche }\end{array}$ & - & 6200.00 & - & - & - & 15.53 & - & - & 83.28 & - & 3.78 & 0.65 & 0.24 & [15] \\
\hline $\begin{array}{l}\text { Sound of } \\
\text { Campeche }\end{array}$ & - & 9050.00 & - & - & - & 9.56 & - & - & 199.23 & - & 0.00 & 0.44 & 5.54 & [16] \\
\hline $\begin{array}{l}\text { Sound of } \\
\text { Campeche }\end{array}$ & - & 6100.00 & - & - & - & 16.01 & - & - & 51.83 & - & 2.38 & 0.40 & 1.31 & [14] \\
\hline $\begin{array}{c}\text { Tampico } \\
\text { Tamaulipas }\end{array}$ & $18,473.82$ & - & - & 354.15 & - & 3617.60 & 246.86 & 266.02 & 970.57 & 59.21 & - & - & 6058.26 & [17] \\
\hline $\begin{array}{c}\text { Tuxpan } \\
\text { Veracruz }\end{array}$ & - & - & - & - & - & 22.00 & - & 17.00 & 257.00 & - & - & - & - & [26] \\
\hline $\begin{array}{c}\text { Tuxpan } \\
\text { Veracruz }\end{array}$ & - & $12,391.31$ & - & - & - & 20.67 & - & - & 261.04 & - & - & - & - & [18] \\
\hline $\begin{array}{c}\text { Tuxpan } \\
\text { Veracruz }\end{array}$ & - & $12,524.98$ & - & - & - & 20.73 & - & - & 266.20 & - & - & - & - & [18] \\
\hline $\begin{array}{c}\text { Tuxpan } \\
\text { Veracruz }\end{array}$ & $40,173.42$ & - & - & 1235.7 & - & $21,955.5$ & $6,013.2$ & 7979.4 & $97,075.4$ & 476.7 & - & - & $15,398.5$ & [17] \\
\hline $\begin{array}{l}\text { Veracruz } \\
\text { Veracruz }\end{array}$ & $155,510.2$ & - & - & 1223.7 & - & $17,038.1$ & 582.59 & 657.60 & 1694.19 & 128.5 & - & - & $24,515.2$ & [17] \\
\hline
\end{tabular}




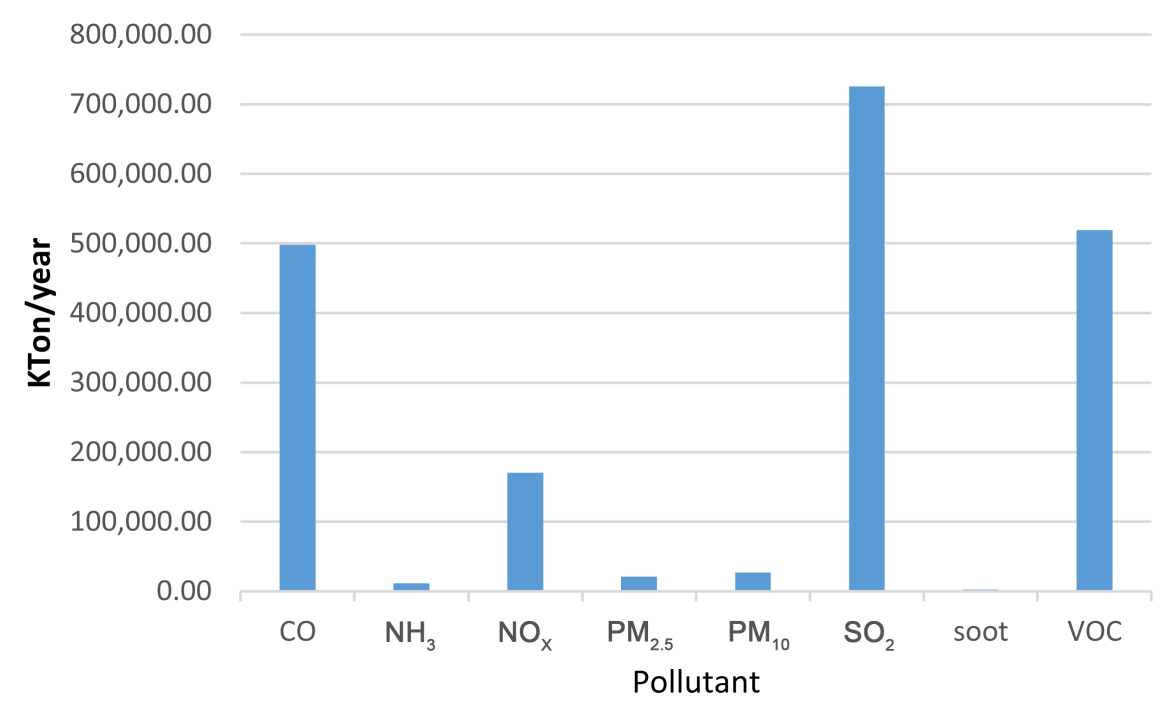

Figure 2. Total pollutants emission (Kton $\cdot \mathrm{yr}^{-1}$ ) in the Gulf of Mexico [17].

Distribution of contributions of different cities to main pollutants, considered in Table 2 and Figure 2 are illustrated in Figure 3. Cities of Coatzacoalcos, Ciudad Madero and Veracruz are the bigger contributors to CO $\left(>67,535 \mathrm{KTon}^{\left.-\mathrm{yr}^{-1}\right)}\right) \mathrm{NO}_{\mathrm{x}}$ emissions are leaded by Ciudad del Carmen $\left(>37,501 \mathrm{KTon}^{-} \mathrm{yr}^{-1}\right)$, this is probably because of oil production presence in this area. Regarding $\mathrm{SO}_{2}$ emissions, Ciudad del Carmen is the greatest producer compared to the rest $\left(>450,000 \mathrm{KTon}^{-} \mathrm{yr}^{-1}\right)$, again oil industry emission are included in this value. This fact is supported by the results reported by Cerón et al. [11] in a study about spatial and temporal distribution of $\mathrm{N}$ and $\mathrm{S}$ deposition fluxes in Ciudad del Carmen, where $\mathrm{S}$ and $\mathrm{N}$ deposition fluxes were high in comparison with critical load values reported for sensitive ecosystems in United States and European countries. In the other hand, $\mathrm{PM}_{2.5}$ and $\mathrm{PM}_{10}$ are mostly produced by industrial facilities in Tuxpan, where a big thermoelectric power plant is operating. VOC's show a strange behavior, while Ciudad del Carmen has the first place $\left(>18,000 \mathrm{KTon} \cdot \mathrm{yr}^{-1}\right)$, Champoton has the second place which is odd, because there is any industry. Regarding this, Cerón et al. [19] reported formaldehyde and acetaldehyde concentrations in air ambient higher than those reported for other authors in Mexico and other sites around the world. In addition, the results obtained during this study indicate that BTEX levels in Carmen City are comparable with those found in big polluted cities. However, it is necessary to assess the source-receptor relation by using models to estimate the contribution of regional and local emissions to the total levels of VOC's in this site.

In counterpart, to the previous EI works, there has been individual assessment works that have been accomplished in some places of oil industry in the Sound of Campeche. These works involved proper source measurements following standard procedures [20]-[25], including sources in some offshore complex and terrestrial petroleum facilities (Pol-A, "Inyección de Agua (Water Injection platform)", Abkatun-A, Abkatun-D, Akal-GC, Pol-Chucand DBMT), where measurements indicated that emission levels were under the maximum allowed by the environmental regulations.

Vijay et al. [18] estimated air pollution emissions from fossil fuel used in the electricity sector in Mexico. This work constitutes one of the few works regarding Thermoelectric Power Plants. Their results include Installed Fossil-fuel-based Generation Capacity and Estimated Emissions for $\mathrm{CO}_{2}, \mathrm{Hg}, \mathrm{NOx}$, and $\mathrm{SO}_{2}$ for Campeche, Tamaulipas, Veracruz and Yucatan (2001-2002). They point out that the use of emission factors is not necessarily the best way to estimate emissions; however, given the lack of any continuous emissions measurements or frequent stack measurements, it is the only feasible option. Even if we assume emission factors to result in good quality estimations, there are several other simplifications and assumptions made that further affect the precision of the estimations, like exact percentage fuel carbon and sulfur content, tangentially fired or normal fired or wall-fired boilers (see Table 2).

Mendoza et al. [9] give a partial EI with different values for different months of the year, which is not consistent with some other EI that are expressed on a year basis [8] [18]. They argue that variations are due to gas/oil relation changes together with oil production and meteorological conditions that affects combustion effi- 


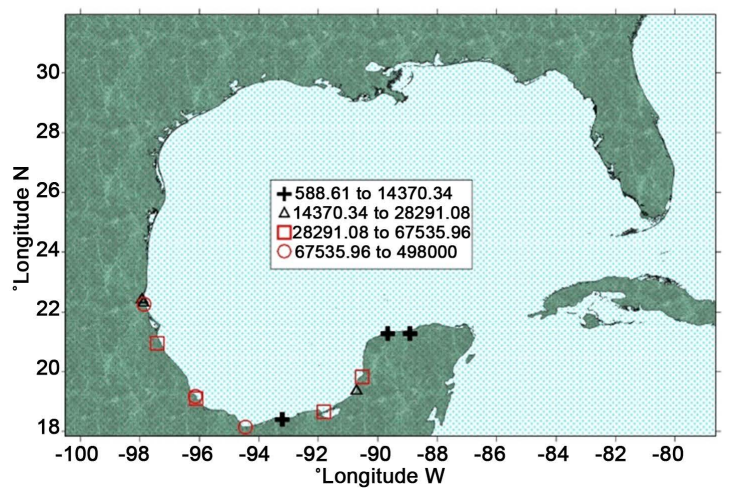

(a)

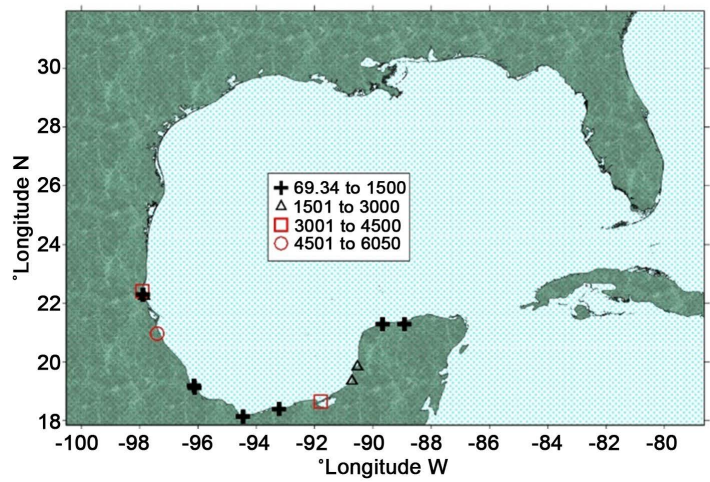

(c)

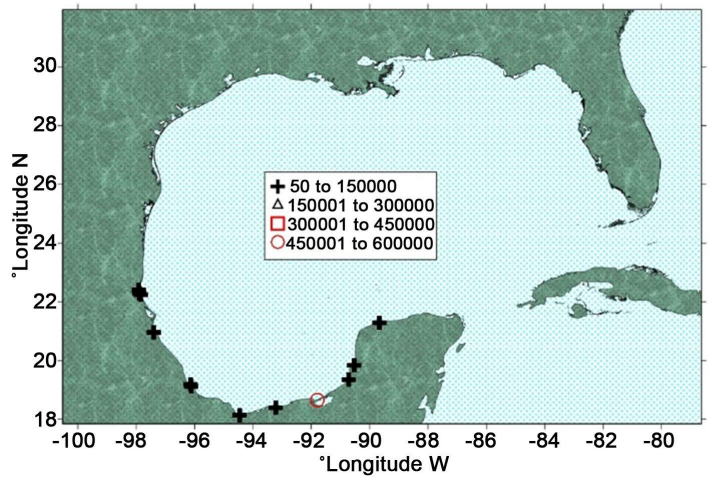

(e)

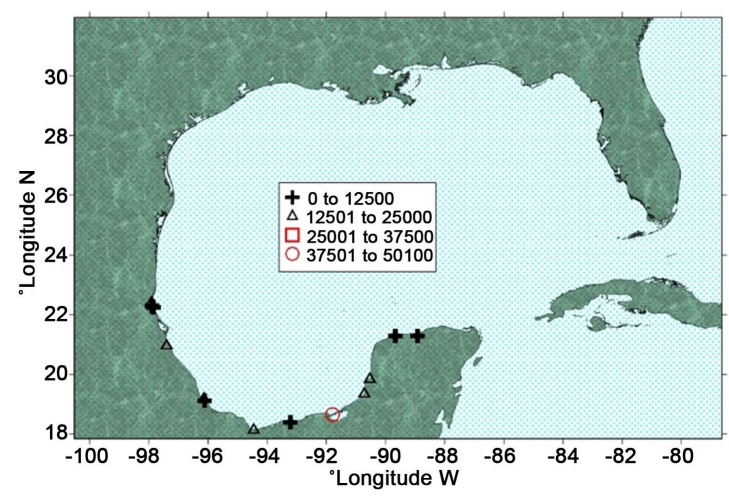

(b)

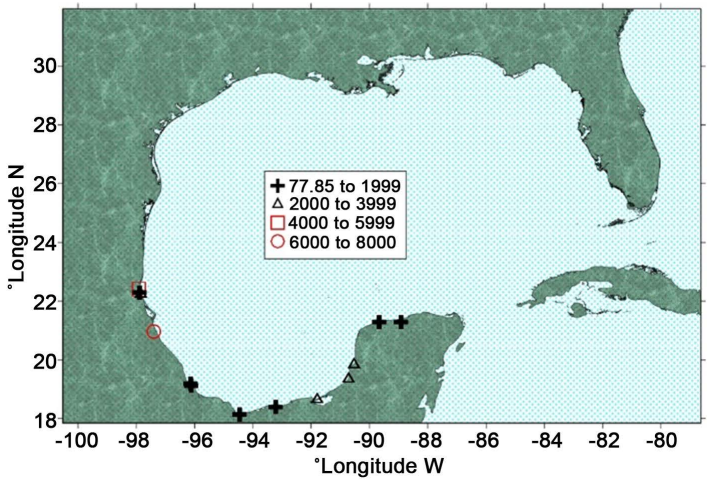

(d)

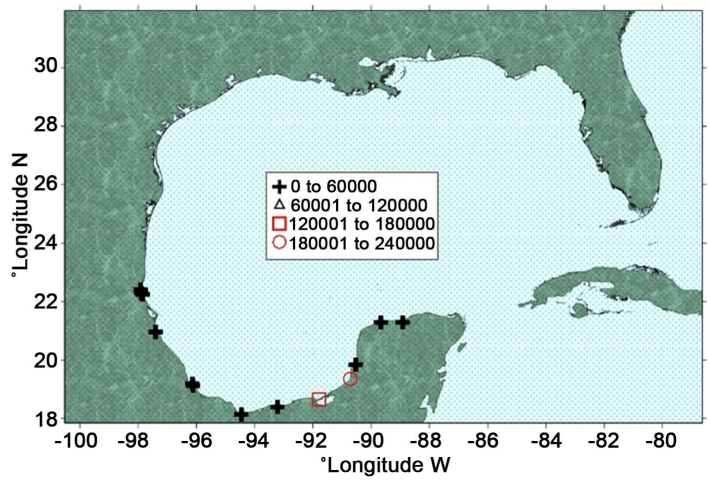

(f)

Figure 3. Pollutants emissions (KTon·yr ${ }^{-1}$ ) in 2008. (a) CO; (b) $\mathrm{NO}_{x}$; (c) $\mathrm{PM}_{2.5}$; (d) $\mathrm{PM}_{10}$; (e) $\mathrm{PM}_{10}$; (f) VOC.

ciency, but they do not give a conclusive weight to each factor. Although their results are consistently lower than Villaseñor's, $\mathrm{H}_{2} \mathrm{~S}$ shows an unexpected higher value (see Table 2).

\section{Air Pollution Monitoring}

If pollutants emissions assessment and diagnosis in the Gulf of Mexico is an activity where there is not enough compromise from Mexican environmental authorities, there is still less involvement in Air Pollution Monitoring (APM). Existing studies are very few and APM information of oil production regions is not public.

A first APM study was registered in April 1990 and took place in the surroundings of Campeche's Thermal Power Plant (site number 12, see Figure 1) [27]. Three points were included and only $\mathrm{SO}_{2}$ and PST were monitored by a short period of time. Obtained results are very preliminary and they have only an historical meaning (see Tables 3-5). 
Table 3. $\mathrm{SO}_{2}$ monitoring results in Lerma, Campeche [20].

\begin{tabular}{cccc}
\hline Monitoring point & $\mathbf{1}$ & $\mathbf{2}$ & $\mathbf{3}$ \\
\hline $\mathbf{Q}$ std $\left(\mathbf{l} \cdot \mathbf{m i n}^{-1}\right)$ & $0.395 / 0.397$ & $0.580 / 0.572$ & $0.598 / 0.592$ \\
$\mathbf{V ~ s t d ~ ( l ) ~}$ & 511.6 & 777.65 & 982.90 \\
$\mathbf{C}\left(\boldsymbol{\mu} \cdot \mathbf{m}^{-3}\right)$ & N.D. & 2.613 & 21.526 \\
$\mathbf{C}(\mathbf{p p m})$ & N.D. & 0.001 & 0.0082 \\
\hline
\end{tabular}

Table 4. PST monitoring results in Lerma, Campeche [20].

\begin{tabular}{cccc}
\hline Monitoring point & $\mathbf{1}$ & $\mathbf{2}$ & $\mathbf{3}$ \\
\hline $\mathbf{V}\left(\mathbf{m}^{\mathbf{3}}\right)$ & 928.19 & 914.18 & 1096.96 \\
$\mathbf{C}\left(\boldsymbol{\mu} \cdot \mathbf{m}^{-3}\right)$ & 59.5 & 68.69 & 223.89 \\
\hline
\end{tabular}

Table 5. Average PST concentration in the Gulf of Mexico [21].

\begin{tabular}{ccc}
\hline \multirow{2}{*}{ Date } & \multicolumn{2}{c}{ PST concentration $\left(\boldsymbol{\mu g} \cdot \mathbf{m}^{-\mathbf{3}}\right)$} \\
\cline { 2 - 3 } & Day & Night \\
\hline $\mathbf{1 9 8 6}$ & $18.4 \pm 4.6$ & $32.1 \pm 9.0$ \\
September-October, 2002 & $15.6 \pm 4.5$ & $13.6 \pm 4.8$ \\
November-December, 2002 & $16.4 \pm 4.4$ & $19.9 \pm 5.0$ \\
September-October, 2003 & $23.6 \pm 4.6$ & $25.7 \pm 5.5$ \\
May-Jun, 2004 & $34.6 \pm 7.0$ & $38.9 \pm 8.1$ \\
\hline
\end{tabular}

Later on Sosa and colleagues [28], in the period 2002-2004, made PST measurements in the Gulf of Mexico]. Basically they measured for a two months period in each reported year, except in 2002 when they made it twice. In this work they also include values obtained previously [29] [30]. They show some statistics for their results, but it can be observed that PST concentrations are very low, as it should be expected for that region. Additionally monitoring periods are short and monitoring points are no source orientated.

During November 2007, the air quality was studied for a short period in three places around DBMT. The limited amount of time for these measurements does not allow doing any valid conclusion, even though standard methods were employed [30].

It is acknowledged that two Monitoring Network were installed in 1997, one in Atasta (a few kilometers from Ciudad del Carmen, Campeche) and other around DBMT (within the Paraíso, Tabasco municipality) [31]. Unfortunately DBMT's network does not exist anymore and Atasta's station has been working very intermittently. Further, information about air quality is not public and monitoring sites are not well positioned, therefore produced information is not quite about pollution produced by main sources in Atasta's region. This might be confirmed by a few of the available public information where it is confirmed that $\mathrm{SO}_{2}$ in the 2003 period had a maximum \% value in DBMT and Atasta of 8.5 and 14, respectively, with regard to maximum allowed level [31]. $\mathrm{NO}_{2}$ showed a similar behavior. Atasta's information can be confirmed through an analysis of 1999-2005 monitoring information made on 2010 [30]. This analysis also concludes that all pollutants ambient concentrations are low.

According to National System of Air Quality Information (SINAICA), Tabasco is the only one state along the coast of the Gulf of Mexico which is registered in this system [32]. The rest of the states located along the coast of the Gulf of Mexico do not have automatic monitoring stations operating regularly. In the case of Veracruz, just this year, one mobile station began to operate in the city of Xalapa; whereas in Campeche State, one fixed station is operating since November 2014. Air quality monitoring in the state of Tabasco began in 1999, this network has also 4 manual stations collecting data of $\mathrm{PM}_{10}$ for 4 main cities in the state: Comalcalco, Cárdenas, Villahermosa and Tenosique. However, excepting $\mathrm{PM}_{10}$, collected information from this network does not meet 
the established criteria for its inclusion in the SINAICA'S reports, therefore, this information is not available. In fact, the performance evaluation report [33] showed that the overall performance of this network is the minimum acceptable and requires a lot of attention. These equipments have never been subjected to audits, negatively impacting on their performance. Regarding to $\mathrm{PM}_{10}$ levels, in Cardenas, Villahermosa and Comalcalco cities during 2003 and 2004, $\mathrm{PM}_{10}$ concentrations exceeded $120 \mu \mathrm{g} \cdot \mathrm{m}^{-3}$, whereas between 2005 and 2007, the maximum values of $\mathrm{PM}_{10}$ for these cities reached levels ranged between 60 to $120 \mu \mathrm{g} \cdot \mathrm{m}^{-3}$. It could indicate that air quality in this region has been progressively improving over time; however, the available information is scarce and does not allow assessing the air quality in a reliable way. Therefore, it can be concluded that there is a general lack of information about air quality in the states of the Gulf of Mexico.

\section{Modeling of Air Pollution Dispersion}

Modeling of air pollution dispersion is an activity that has been done a few times form this region. One of this studies was done in Tuxpan Power Plant [26] [34], three others were done in the Sound of Campeche [8] [9] [12], one in DBMT [20] and one in Atasta Processing Center [35].

Making use of EI produced in 1997, for the oil industry operations in the Sound of Campeche [20], together with 1995 meteorological information of the same region [12] to feed Ocean and Coastal Dispersion Model (OCD) [36], the first air pollution dispersion exercise was accomplished in order to envisage if air pollution emissions from oil industry in the Sound of Campeche were impacting the environment, according to environmental regulations [12]. It might be discussed if the use of OCD is a good option, while there is some more powerful dispersion models e.g. AERMOD [37] [38], there are a few reasons to be considered. First, most of oil industry operations in the Sound of Campeche are offshore, so there are two scenarios at least: off shore and in shore operations. Second, off shore operations are far from main land, so pollutants will be under a big dilution process and free from obstacles, before reaching land. Third, advanced models need more meteorological information which is not available even at the present time. Fourth, in order to use advanced models, some meteorological information can be retrieved from available data bases and make some interpolation to get local met data. Nevertheless, this will be as imprecise or even more than employing a Gaussian model. Fifth, OCD is a straight line Gaussian model developed to determine the impact of offshore emissions from point, area or line sources on the air quality of coastal regions and incorporates overwater plume transport and dispersion as well as changes that occur as the plume crosses the shoreline. Results for 1997 dispersion modeling are shown in Figure 4 and Figure 5.

It is interesting to observe that this first approach reveals the no impact, on average, of southwest oil industry operations in the Sound of Campeche. This result make considered arguments, in previous paragraph to be stronger.

Lopez and collaborators studied health impacts from power plant emissions in Mexico [35]. They obtained ambient annual average concentrations for Tuxpan Power Plant during 2001 [31]. Main results for $\mathrm{PM}_{2.5}$ and $\mathrm{SO}_{2}$ are 0.12 and $3.09 \mu \mathrm{g} \cdot \mathrm{m}^{-3}$, respectively. Air Quality Standards for $\mathrm{PM}_{2.5}$ and $\mathrm{SO}_{2}$ annual average are 15 and $79 \mu \mathrm{g} \cdot \mathrm{m}^{-3}$. It is stated that Tuxpan is the largest power plant emitter of $\mathrm{SO}_{2}$ in North America with emissions intensities approximately 50\% greater than the Mexican average (4.5 times the US average) and $\mathrm{PM}_{2.5}$ emissions are 10 times higher than the US average (38\% times greater than Mexican average) due to lack of emissions controls and to the high-sulfur content of the "combustóleo". Even tough is obvious, that calculated ambient concentrations are much lower than Mexican quality standards.

Later on another pollution dispersion exercise at the Sound of Campeche was done by Villaseñor et al. in 1999 [8]. For this study they used CALMET [39] and CALPUFF [38] and included all sources from oil industry in the region. They results confirm the no impact or air pollution emission, consequently confirms previous result using OCD.

Another work using HYPACT [40] and RAMS [41] was done in the locality of Paraiso in Tabasco State [12]. For this effort surface meteorological information of 2005 was available. Upper meteorology was obtained from Veracruz, Mérida and Acapulco [42] and global meteorological data were obtained from the National Center for Environmental Prediction [37]. In order to do a more comprehensive modeling study, five meteorological scenarios were chosen:

1) February, 14-16,

2) April, 21-23,

3) June, 09-11, 


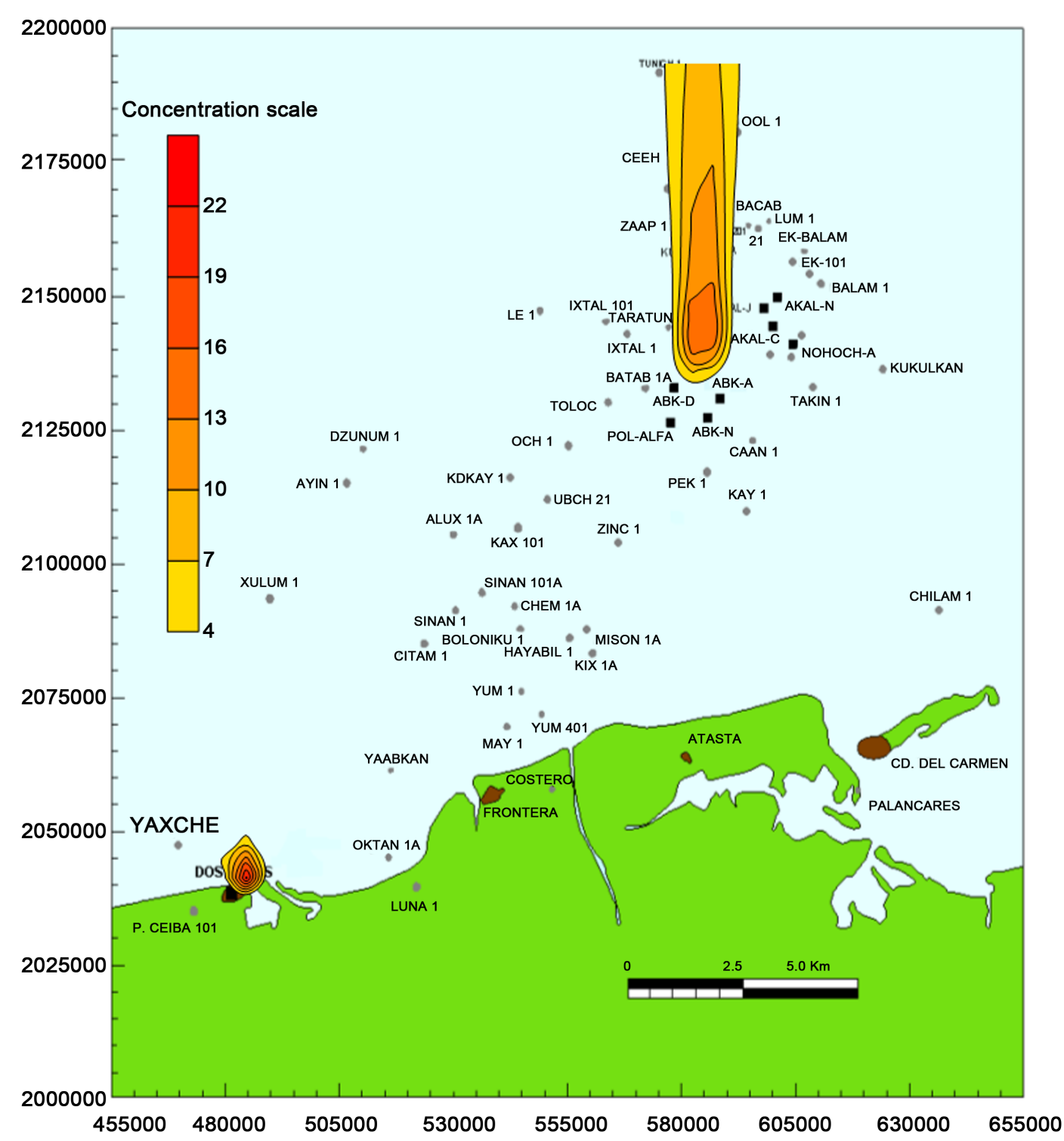

Figure 4. Average $24 \mathrm{hr} . \mathrm{SO}_{2}$ concentration $\left(\mu \mathrm{g} \cdot \mathrm{m}^{-3}\right)$ produced by maximum emissions of the south west oil industry process.

4) October, 17-19,

5) December, 18-20.

Sometimes, it was observed a presence of a maritime air in the north or northeast direction. Land air is less frequent, showing a southeast or south-southwest direction. Additionally analysis of dispersion results reveals that air quality standards are not exceeded in all 2005 year. Most significant scenarios are depicted in Figure 6 and Figure 7 [20].

Mendoza and Graniel [43] made another study in the Sound of Campeche, using a previous EI [9] which has been discussed before. This work employed California/Carnegie Institute of Technology (CIT) version 3.0 model, which is a tri-dimensional model that describes pollutants dynamics through atmosphere [44]. They also included a modified version of SPARC90 photochemical mechanism [45].

Modeled scenarios were the same for EI periods reported previously [10]. They found maximum concentration values for low wind speed values (1 to $2 \mathrm{~m} \cdot \mathrm{s}^{-1}$ ) in the December 2000-January 2001 period, which is different to Villaseñors' result [8], but they also conclude that maximum ambient concentrations did not exceeded maximum allowed levels. This result is similar to those found by Muriel [12] and Villaseñor [8]. 


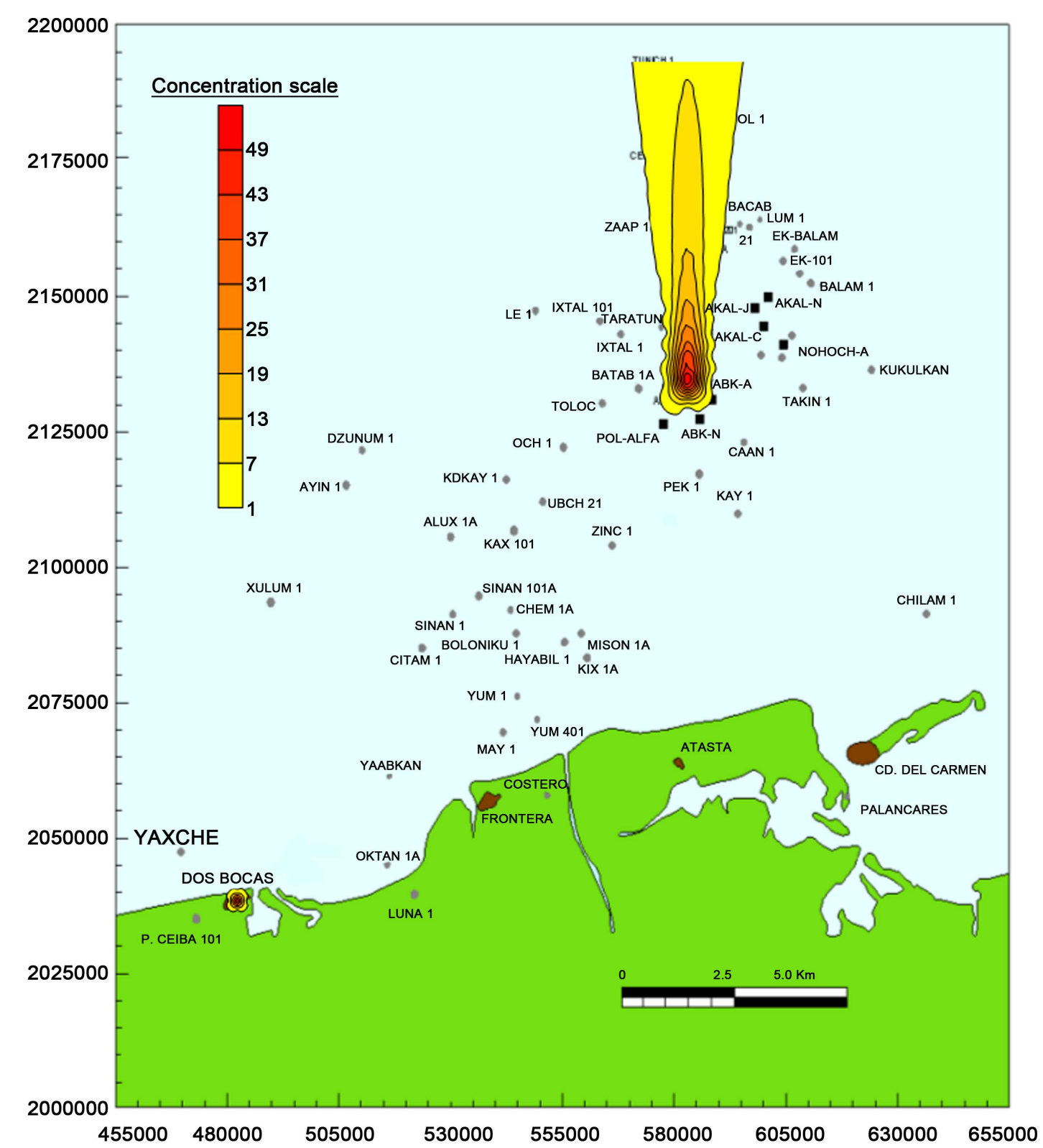

Figure 5. Average $1 \mathrm{hr}$. NOx concentration $\left(\mu \mathrm{g} \cdot \mathrm{m}^{-3}\right)$ produced by maximum emissions of the south west oil industry process.

More recently, in 2010 another dispersion modeling study for the Atasta Region was made, which is $36 \mathrm{~km}$ to west from Ciudad del Carmen [34]. An atmospheric vertical profile was included and covered from august 31 to September 4, 2010. Results indicated a stable meteorological condition at synoptic level, with the presence of an anticyclone system in the Gulf of Mexico. Ciudad del Carmen surface meteorology was analyzed for 2007 to 2010 period, showing a most frequent wind component form east-southeast. In order to establish the circumstances where dispersion is less favored and the highest ambient concentrations are expected, the most critical scenario for modeling pollution dispersion was selected. This section was made having in mind four conditions: the most frequent wind direction must be considered; average wind intensity must be near to $2.5 \mathrm{~m} / \mathrm{s}$; average temperature must be around $29^{\circ} \mathrm{C}$; and relative humidity should be between $77 \%$ and $88 \%$. Therefore the selected critical period was from September 17 to September 20, 2010. Under this scenario, the Regional Atmospheric Meteorological Model [41] was applied using reanalysis information [42], three nested grids with horizontal spacing of 40, 10 and $1 \mathrm{~km}$, surface data from Carmen, CayoArcas, Eco, Rebombeo, Kuh and Dos Bocas 


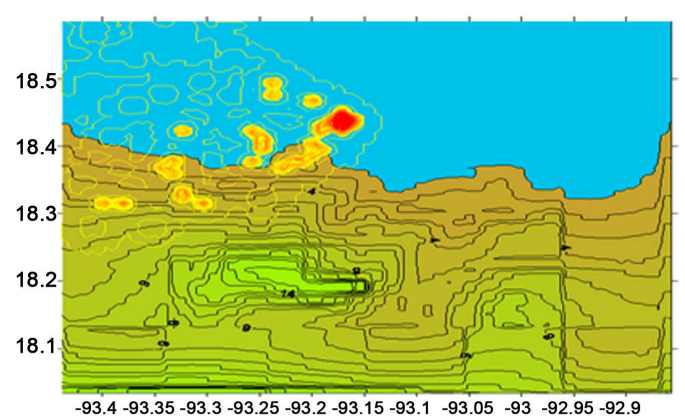

(a)

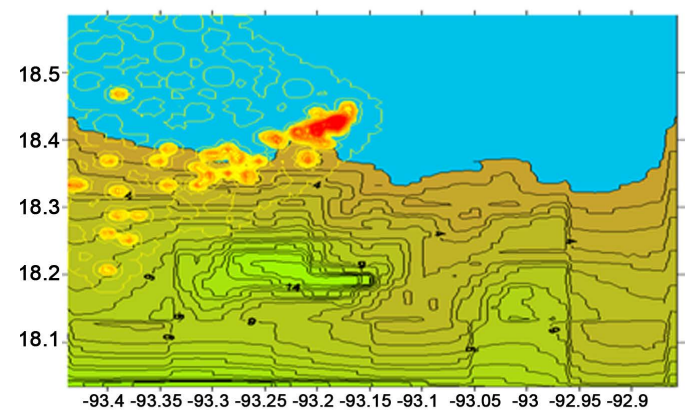

(c)

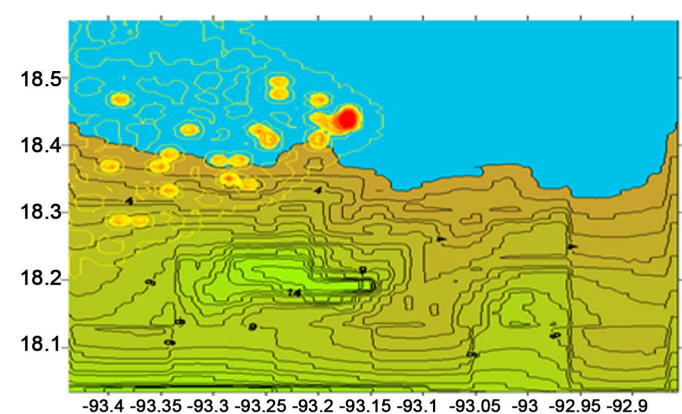

(b)

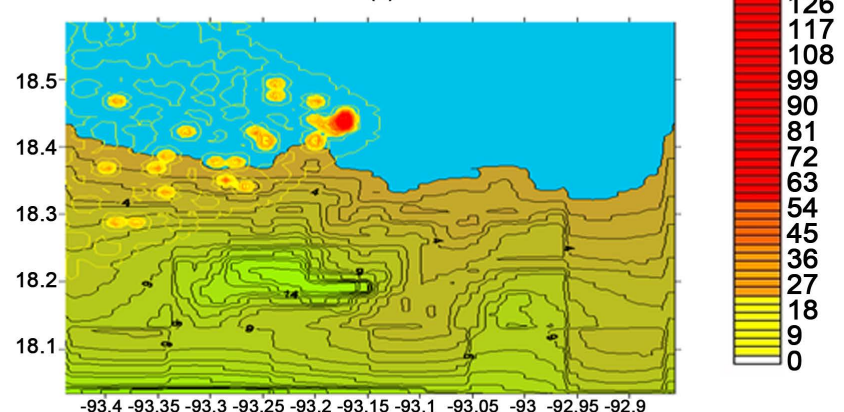

(d)

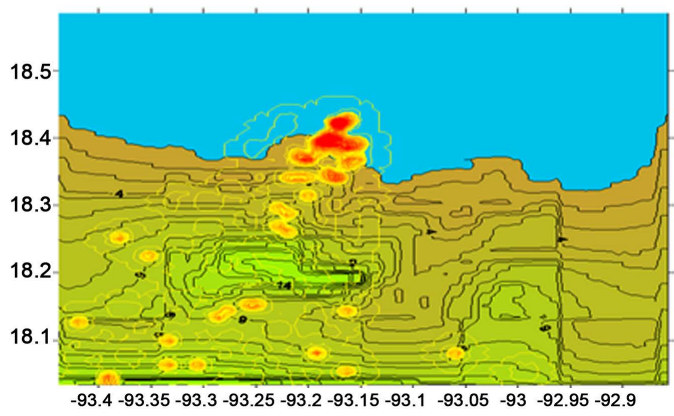

(e)

Figure 6. Air pollution dispersion for scenario No 1 in year 2005. (a) April 22, 00 h; (b) April 22, 12 h; (c) April 23, 00 h; (d) April 23, 12 h; (e) April 24, 00 h.

Maritime Terminal (DBMT) and upper meteorology from Veracruz, Mérida and Acapulco [42]. Having done meteorological modeling, dispersion calculation was completed by means of CALPUFF [37] [38]. Main results illustrate that most of pollution plumes follow a southeast and east-southeast direction and maximum concentrations at floor level do not exceed $\mathrm{SO}_{2}$ regulations (Figure 8). The rest of pollutants showed the same behavior [34].

Cerón et al. [46] [47] studied N and S atmospheric deposition fluxes as nitrate and sulfate, respectively during one year, demonstrating that during Norths season, both, Ciudad Del Carmen and Atasta, are subjected to the influence of long-range transport, so that sulfate levels are increased as a result of regional transport. From analysis of air masses trajectories, Cerón et al. [46] [47] conclude that prevailing winds come from NE during cold fronts or Norths season, and it has been reported that main sources improving sulfate background levels in this region are offshore platforms in the Sound of Campeche. Therefore, air pollution dispersion modeling in the Sound of Campeche considering longer periods of time is required. Also, it is necessary to obtain complete data at least in an annual basis, allowing to consider different meteorological scenarios, and to assess the contribution of regional sources during Norths season. Regarding to air dispersion models, the main limitation in most of studies reported here is that modeling studies have not only been made during short periods of time but also much of the information used is obtained from reanalysis data, resulting in a general lack of meteorological information in this region. 


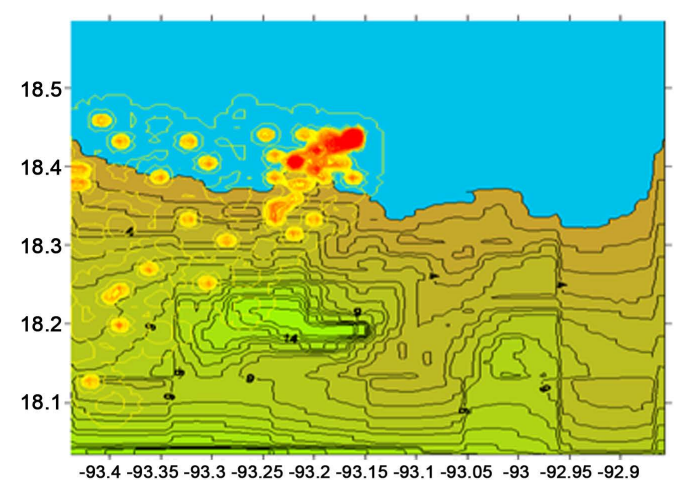

(a)

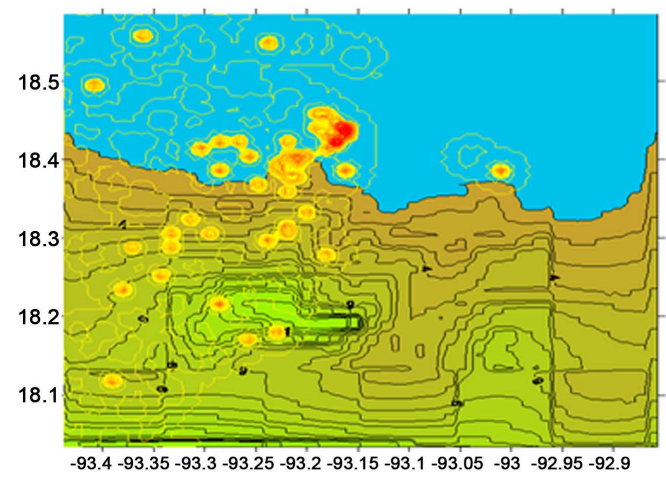

(c)

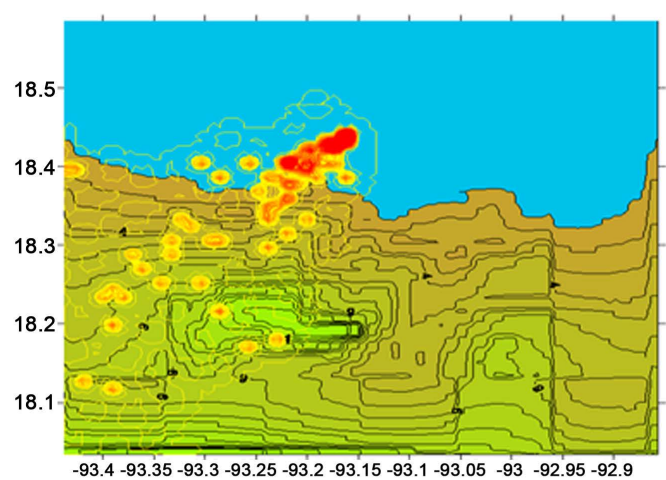

(b)

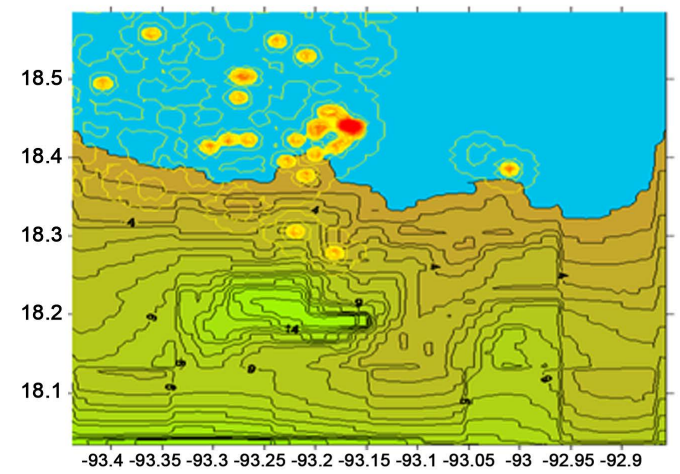

(d)
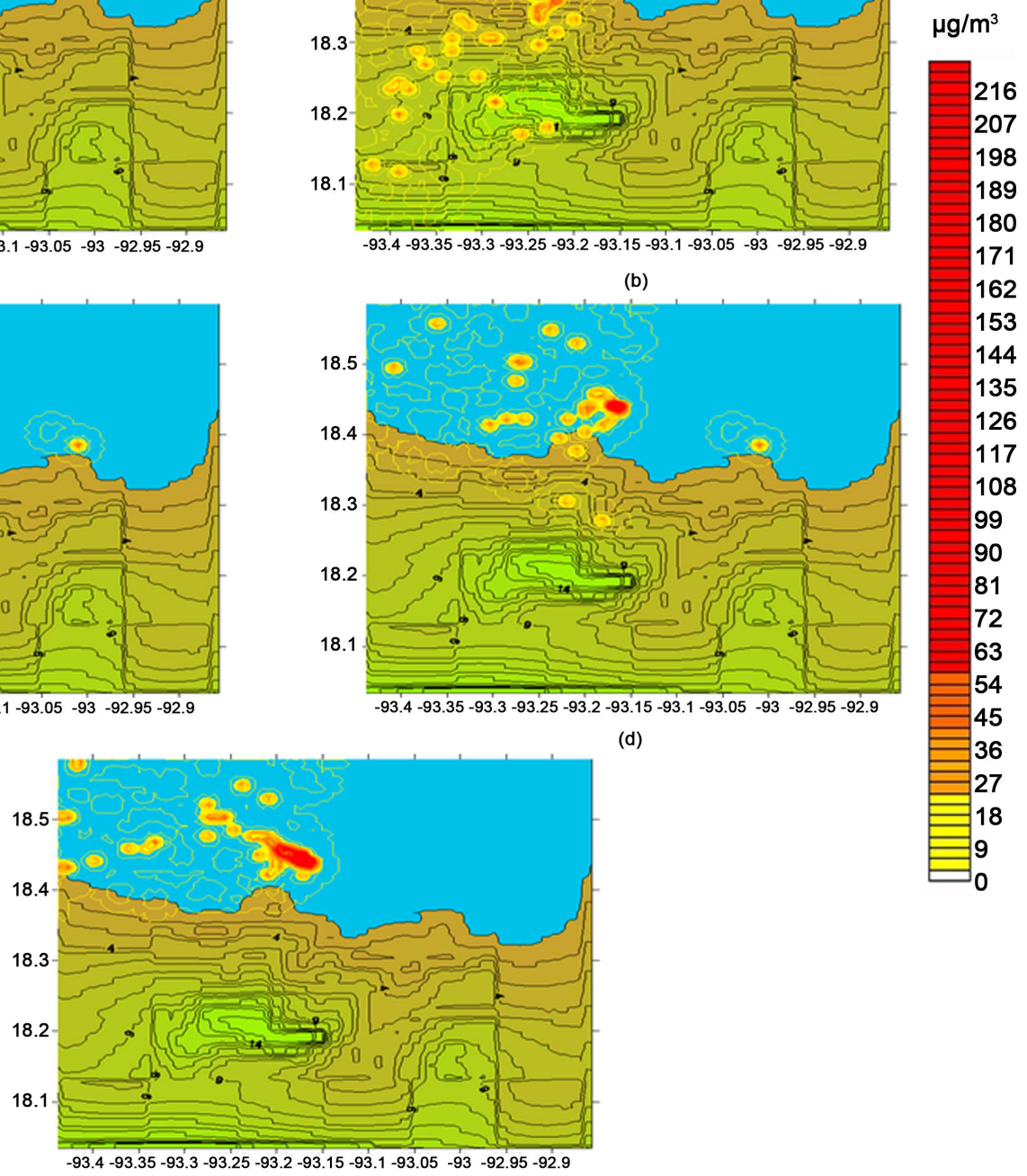

(e)

Figure 7. Air pollution dispersion for scenario No 2 in year 2005. (a) June 10, 00 h; (b) June 10, 12 h; (c) June 11, 00 h; (e) June 12, 00 h; (e) June, 00 h.

\section{Conclusions}

This review makes evident a lack of more recent information and there is not sufficient detail in most of it, therefore it makes difficult to have a proper panorama to be in position to establish appropriate policies and regulations to control air pollution emissions. It is important to homogenize emission factor that can be used systematically for all actors and to make emissions measurement a compulsory activity, so reliable EI could be produced. Dispersion modeling made evident that primary pollutants were not impacting air quality. On the other hand, monitoring results and atmospheric deposition studies demonstrated that $\mathrm{SO}_{2}$ and sulfate levels could be a severe environmental problem in this region. Consequently, it is important to put more effort in dispersion modeling, which is a less expensive activity. In addition, some attention must be given to acid rain, mercury and carcinogenic organic compounds that are directly produced or might be a secondary transformation product.

It is very important that environmental authorities make a further effort to make public EI as well as results of monitoring air pollution from all sources, especially those who are producing or are suspected to produce an en- 


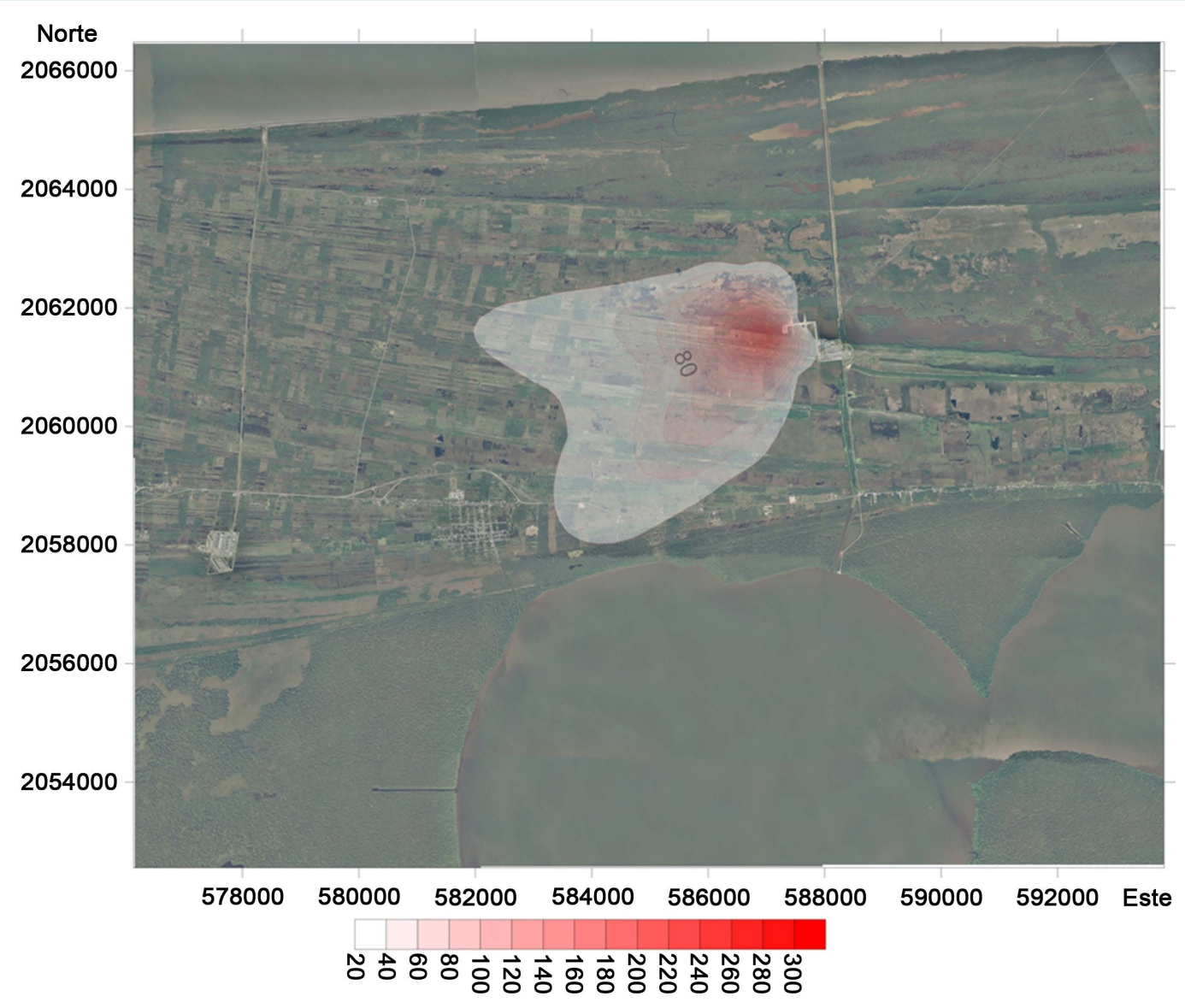

Figure 8. Average $\mathrm{SO}_{2} 8$ hr. concentration. September 2009.

vironmental impact. Even more, there should be a more complete environmental regulations specifying what to measure, when to measure and where to measure, this will guarantee that available budget is used more efficiently. Authorities, industry, academics and engineers should put more effort in making dispersion modeling a standard tool, similar as it is done in the USA [48]. Contrary to that reported from monitoring studies, at this moment, in the Sound of Campeche, Atasta, and Paraiso it has been demonstrated through dispersion modeling that there is not air pollution impact for the presence of $\mathrm{SO}_{2}, \mathrm{NO}_{\mathrm{X}}$ and particles. However, it is necessary to achieve intensive monitoring campaigns that collect criteria pollutants data at a wide scale, to carry out campaigns to obtain full database of surface and upper meteorology, and to increase the number of measuring points, either by purchasing automatic equipment or by using passive or manual samplers. This will allow assessing the air quality in the region, both spatially and temporally, identifying critical points that can be compared with the critical points obtained from models. Integral studies that simultaneously consider both monitoring and modeling are required, so that, those periods where background levels could have a strong regional contribution are identified. From this, it will be possible to obtain a solid base line and sufficient database that allows validating the results obtained from modeling studies.

\section{References}

[1] INECC (2015). www.inecc.gob.mx/calaire-informacion-basica/551-calaire-inv-emision

[2] INE (2006) National Emissions Inventory 1999. 1st Edition, Instituto Nacional de Ecología (INE)/Secretaría de Medioambiente y Recursos Naturales, México DF.

[3] Benítez, J.A., Cerón, R.M., Cerón, J.G., Roé, B. and Rendón, J. (2014) Environmental Impact Due to the Population Growth and Economical Activities in the Gulf of Mexico: Land Use and Waste Generation. In: Botello, A.V., Rendón Von Osten, J., Benítez, J.A. and Gold Bouchot, G., Eds., Gulf of Mexico, Environmental Impact: Diagnosis and Trends. 3rd Edition, Vol. II, Universidad Autónoma de Campeche-Universidad Nacional Autónoma de México-Centro de 
Investigación y Estudios Avanzados IPN Unidad Mérida. Campeche, Campeche, 747-762.

[4] Mejía, G.M. and Rodríguez, M. (1997) Characteristics and Estimated Air Pollution Emissions from Fuel Burning by the Industry and Vehicles in the Matamoros-Reynosa Border Región. Environment International, 23, 733-744. http://dx.doi.org/10.1016/S0160-4120(97)00072-X

[5] Báez, A., Padilla, H., Cervantes, J., Pereyra, D. and Belmont, R. (1997) Rainwater Chemistry at the Eastern Flanks of the Sierra Madre Oriental, Veracruz, Mexico. Journal of Geophysical Research, 102, 329-336. http://dx.doi.org/10.1029/97jd02077

[6] Bravo, H., Soto, R., Sosa, R., Sánchez, P., Alarcon, A., Kahl, J. and Ruíz, J. (2006) Effects of Acid Rain on Building Material of the El Tajin Archaecological Zone in Veracruz, Mexico. Environmental Pollution, 144, 655-660. http://dx.doi.org/10.1016/j.envpol.2005.12.052

[7] Kahl, J., Bravo, H., Sosa, R., Sánchez, P., Alarcon, A. and Soto, R. (2007) Characterization of Atmospheric Transport to the El Tajin Archaecological Zone in Veracruz, Mexico. Atmosfera, 20, 359-371.

[8] Villasenor R., Magdalena, M., Quintanar, A., Gallardo, J.C., López, M.T., Jurado, R., Miranda, A., Aguilar, M., Melgarejo, L.A., Palmerín, E., Vallejo, C.J. and Barchet, W.R. (2003) An Air Quality Emission Inventory of Offshore Operations for the Exploration and Production of Petroleum by the Mexican oil Industry. Atmospheric Environment, 37, 3713-3729. http://dx.doi.org/10.1016/S1352-2310(03)00445-X

[9] Schifter, I., González-Macías, C., Miranda, A. and Lpez-Salinas, E. (2005) Air Emissions Assessment from Offshore Oil Activities in Sonda de Campeche, Mexico. Environmental Monitoring and Assessment, 109, 135-145. http://dx.doi.org/10.1007/s10661-005-5844-6

[10] Mendoza, A. and Graniel, M. (2006) Estimate of Emissions to the Atmosphere from Open Flares in Petroleum Facilities in the Sound of Campeche. Ingenier za, Investigación y Tecnologıa, 7, 165-173.

[11] Cerón, R.M., Cerón, J.G., Muriel, M., Anguebes, F., Ramírez, M., Zavala, J., Carballo, C. and Escoffie, R.C. (2015) Spatial and Temporal Distribution of Throughfall Deposition of Nitrogen and Sulfur in the Mangrove Forests Associated to Terminos Lagoon. In: Nejadkoorki, F., Ed., Current Air Quality Issues, Chap. 7, InTech, Rijeka, 147-164. http://dx.doi.org/10.5772/59726

[12] Muriel, M. (1999) Environmental Quality Assessment in the Marine and Coastal Zone of Southwest Marine Region of P.E.P; Atmospheric System. Phase I. Instituto Mexicano del Petroleo, P.00592.

[13] Muriel, M. (1999) Environmental Quality Assessment in the Marine and Coastal Zone of Southwest Marine Region of P.E.P; Atmospheric System. Phase II. Instituto Mexicano del Petroleo, P.00602.

[14] PEMEX (2005) Safety, Health and Environment. Annual Report 2005, Petroleos Mexicanos.

[15] PEMEX (2002) Safety, Health and Environment. Annual Report 2002, Petróleos Mexicanos.

[16] PEMEX (2000) Safety, Health and Environment. Annual Report 2000, Petroleos Mexicanos.

[17] SEMARNAT (2008) SINEA, National Emissions Inventory 2008. http://www.inecc.gob.mx/descargas/calaire/2014_inf_fin_moves.pdf

[18] Vijay, S., Molina, L.T. and Molina, M.J. (2004) Estimating Air Pollution Emissions from Fossil Fuel Use in the Electricity Sector in Mexico.

[19] Cerón, J.G., Cerón, R.M., Benítez, J.A., Ramírez, E., Guevara, E. and Córdova, A. (2015) Volatile Organic Compounds Levels in Ambient Air in a Site Located at Terminos Lagoon (2011-2012). In: Botello, A.V., Rendón Von Osten, J., Benítez, J.A. and Gold Bouchot, G., Eds., Gulf of Mexico, Environmental Impact: Diagnosis and Trends, 3rd Edition, Vol. II, Universidad Autónoma de Campeche-Universidad Nacional Autónoma de México-Centro de Investigación y Estudios Avanzados IPN Unidad Mérida, Campeche, 719-742.

[20] Muriel, M. (2007) Atmospheric Emission Inventory Update of Dos Bocas Maritime Terminal. Instituto Mexicano del Petroleo, PS-SMA-IF-F.32835-08.

[21] Muriel, M. (2005) Assessment of Atmospheric Pollution Emissions Sources in ABKATUN-POL-CHUC Premises. Instituto Mexicano del Petroleo, PS-MAS-IG-F.32721-3000-01.

[22] Muriel, M. (2005) Atmospheric Emission Inventory Update of Dos Bocas Maritime Terminal. Instituto Mexicano del Petroleo, PS-MAS-IG-F.32712-3000-01.

[23] Muriel, M. (2002) Atmospheric Emissions Monitoring in ABKATUN-A and ABKATUN-D Oil Production Complexes. Instituto Mexicano del Petroleo, F.30333.

[24] Muriel, M. (2002) Atmospheric Emissions Monitoring in POL-A and WATER INYECTION Oil Production Complexes. Instituto Mexicano del Petroleo, F.30333.

[25] Muriel, M. (2002) Atmospheric Pollution Emissions Measurement in AKAL-C Platform. Instituto Mexicano del Petroleo, F.33846.

[26] López Villegas, M.T., Tzintzun Cervantes, M.G., Iniestra Gómez, R., Garibay Bravo, V., Zuk, M., Rojas Bracho, L. 
and Fernández Bremautz, A. (2004) Evaluating the Impacts of Power Plant Emissions in Mexico. 9th International Conference on Harmonisation within Atmospheric Dispersion Modelling for Regulatory Purposes, Garmisch-Partenkirchen, 1-4 June 2004, 385-389.

[27] Muriel, M. and Romero, B.I. (1990) Initial Study of the Concentration of Atmospheric Pollutants in the Neighbourhoods of Lerma TPP. Instituto de Investigaciones Eléctricas, Departamento Combustibles Fósiles, IIE/12/2086/I 230/P.

[28] Sosa-Echeverria, R., Bravo-Alvarez, H., Sánchez-Alvarez, P., Soto-Ayala, R., Alarcón-Jimenez, A. and Kahl, J.D.W. (2007) TSP Measurement in Five Research Cruises in the Continental Platform of the Gulf of Mexico. Ingenieria, Investigacion y Tecnologia, 8, 71-83.

[29] Parungo, J.F. and Miller, J. (1988) Air-Chemistry Studies over the Gulf of Mexico: A Bilateral Scientific Cooperative Project between the United States of America and the United States of Mexico. Technical Memo, National Oceanic and Atmospheric Administration, Boulder.

[30] Parungo, F., Nagamoto, C., Hoyt, S. and Bravo, A.H. (1990) The Investigation of Air Quality and Acid Rain over the Gulf of Mexico. Atmospheric Environment. Part A. General Topics, 24, 109-123. http://dx.doi.org/10.1016/0960-1686(90)90446-T

[31] Quintero-Mármol, A.M., Rodríguez, M.H. and Pascualli, G.O. (2004) Environmental Monitoring of Oil Industry Activity in South of the Gulf of Mexico, In: Rivera-Arriaga, E., Villalobos-Zapata, G.J., Azuz-Adeath, I. and RosadoMay, F., Eds., Coastal Management in México, Chap. 43, Universidad Autnoma de Campeche, Campeche, 589-610.

[32] SINAICA (2015) http://sinaica.inecc.gob.mx/informa redes.html

[33] SEMARNAT (2011) Fourth Calendar of data and Trends in Air Quality in 20 Mexican Cities (2000-2009). Instituto Nacional de Ecología, México, D.F.

[34] Muriel, M. (2010) Pollutants Dispersion Modelling and Optimal Site Setting of Air Pollution Monitoring Stations of Atasta Gas Transport and Process Center. Instituto Mexicano del Petroleo, PS-SMA-IF-F.33010-03.

[35] Lopez, M.T., Zuk, M., Garibay, V., Tzintzun, G., Iniestra, R. and Fernandez, A. (2005) Health Impacts from Power Plant Emissions in Mexico. Atmospheric Environment, 39, 1199-1209. http://dx.doi.org/10.1016/j.atmosenv.2004.10.035

[36] Chang, K.J. and Hanna, J.C. (1997) User’s Guide for Offshore and Coastal Dispersión (OCD) Model. Versión 5, US Department of the Interior, Minerals Management Service and Gulf of Mexico OCS Región.

[37] USEPA (2014) AERMOD Modeling System. http://www.epa.gov/ttn/scram/dispersion_prefrec.htm\#aermod

[38] USEPA (2014) CALPUFF Modeling System. http://www.epa.gov/ttn/scram/dispersion_prefrec.htm\#calpuff

[39] Scire, J.S., Francoise, R.B., Fernau, M.E. and Yamartino, M.J. (1997) A User's Guide for the CALMET Meteorological Model (Version 5.0). Earthtech Inc., Concord.

[40] Walko, R.L., Tremback, C.J. and Bell, M.J. (2001) Hybrid Particle and Concentration Transport Model. Version 1.2.0. http://www.atmet.com/html/docs/hypact/1.2.0/hyp_ug-1.2.0.htm

[41] Pielke, R.A., Cotton, W.R., Walko, R.L., Tremback, C.J., Lyons, W.A., Grasso, L.D., Nicholls, M.E., Moran, M.D., Wesley, D.A., Lee, T.J. and Copeland, J.H. (1992) A Comprehensive Meteorological Modeling System-RAMS. Meteorology and Atmospheric Physics, 49, 69-91. http://link.springer.com/article/10.1007/BF01025401 http://dx.doi.org/10.1007/bf01025401

[42] NOAA (2014) NOAA/ESRL Radiosonde Database. http://esrl.noaa.gov/raobs/

[43] Mendoza, A. and Graniel, M. (2007) Atmospheric Emissions Diagnosis of Gas Burners in Oil Platforms in the Sound of Campeche. Revista Internacional de Contaminación Ambiental, 23, 99-113.

[44] McRae, G.J., Goodin, W.R. and Seinfeld, J.H. (1982) Numerical Solution of the Atmospheric Diffusion Equation for Chemically Reacting Flows. Journal of Computational Physics, 45, 1-42. http://dx.doi.org/10.1016/0021-9991(82)90101-2

[45] Carter, W.P.L. (1990) A Detailed Mechanism for the Gas-Phase Atmospheric Reactions of Organic Compounds. Atmospheric Environment. Part A. General Topics, 24, 481-518. http://www.sciencedirect.com/science/article/pii/0960168690900058 http://dx.doi.org/10.1016/0960-1686(90)90005-8

[46] Cerón, R. and Cerón, J. (2015) Wet and Dry Deposition of Trace Elements in Two Sites in Carmen Island, Campeche, Mexico. WSEAS Transactions on Environment and Development, 10, 393-403.

[47] Cerón, R., Cerón, J., Aguilar, C., Montalvo, C., Rustrián, E., Houbron, E., Ramírez, M., Muriel, M., Córdova, A., Carballo, C., García, A., Chi, H. and Hernández, M. (2015) Spatial and Temporal Troughfall Deposition Patterns on Two Regions at the Center and at the Southeast of Mexico. WSEAS Transactions on Environment and Development, 11, 57-72.

[48] USEPA (2015) Technology Transfer Network Support Center for Regulatory Atmospheric Modeling. http://www.epa.gov/scram001/ 